OPEN ACCESS

Edited by:

Chaomin Sun

Institute of Oceanology (CAS), China

Reviewed by:

Santosh Kr Karn,

National Institute of Technology

Raipur, India

Adelaide Almeida,

University of Aveiro, Portugal

*Correspondence:

Linzhang Yang

lzyang@issas.ac.cn

Specialty section:

This article was submitted to

Microbiotechnology, Ecotoxicology

and Bioremediation,

a section of the journal

Frontiers in Microbiology

Received: 11 December 2016

Accepted: 21 April 2017

Published: 23 May 2017

Citation:

He S, Zhong L, Duan J, Feng Y,

Yang $B$ and Yang $L$ (2017)

Bioremediation of Wastewater by Iron

Oxide-Biochar Nanocomposites

Loaded with Photosynthetic Bacteria.

Front. Microbiol. 8:823.

doi: 10.3389/fmicb.2017.00823

\section{Bioremediation of Wastewater by Iron Oxide-Biochar Nanocomposites Loaded with Photosynthetic Bacteria}

\author{
Shiying He', Linghao Zhong' ${ }^{2}$, Jingjing Duan', Yanfang Feng ${ }^{1}$, Bei Yang ${ }^{1}$ and \\ Linzhang Yang ${ }^{1 *}$ \\ ${ }^{1}$ Institute of Agricultural Resources and Environment, Jiangsu Academy of Agricultural Sciences, Nanjing, China, \\ ${ }^{2}$ Department of Chemistry, Pennsylvania State University, Mont Alto, PA, United States
}

It has been reported that bacteria-mediated degradation of contaminants is a practical and innocuous wastewater treatment. In addition, iron oxide nanoparticles (NP) are wastewater remediation agents with great potentials due to their strong adsorption capacity, chemical inertness and superparamagnetism. Therefore, a combination of NPs and microbes could produce a very desirable alternative to conventional wastewater treatment. For this purpose, we first prepared $\mathrm{Fe}_{3} \mathrm{O}_{4} /$ biochar nano-composites, followed by loading photosynthetic bacteria (PSB) onto them. It was found that $\mathrm{Fe}_{3} \mathrm{O}_{4} /$ biochar nano-composites exhibited a high adsorption capacity for PSB $\left(5.45 \times 10^{9}\right.$ cells $\left./ \mathrm{g}\right)$. The efficiency of wastewater pollutants removal by this $\mathrm{PSB} / \mathrm{Fe}_{3} \mathrm{O}_{4} /$ biochar agent was then analyzed. Our results indicated that when loaded onto $\mathrm{Fe}_{3} \mathrm{O}_{4}$ /biochar nano-composites, PSB's nutrient removal capability was significantly enhanced $(P<0.05)$. This agent removed $83.1 \%$ of chemical oxygen demand, $87.5 \%$ of $\mathrm{NH}_{4}^{+}$, and $92.1 \%$ of $\mathrm{PO}_{4}^{3-}$ from the wastewater in our study. Our experiments also demonstrated that such composites are outstanding recyclable agents. Their nutrient removal capability remained effective even after five cycles. In conclusion, we found the $\mathrm{PSB} / \mathrm{Fe}_{3} \mathrm{O}_{4} /$ biochar composites as a very promising material for bioremediation in the wastewater treatment.

Keywords: iron oxide nanoparticles, nanocomposites, microorganisms, biochar, nutrient removal, water treatment

\section{INTRODUCTION}

Water pollution remains as an enduring environmental problem that accompanies with worldwide human population increase and economic development. The organic pollutants, excessive phosphorous $(\mathrm{P})$ and nitrogen $(\mathrm{N})$ released through runoff, frequently result in the eutrophication of water bodies, which is harmful to the health of human beings and to the ecological environment (Beaver et al., 2014; Kirkpatrick et al., 2014; Li et al., 2014). It is desirable to establish environmentally benign and economically cost-effective measures to keep such pollutions under control. Significant efforts have already been made to improve wastewater treatment with different approaches, such as adsorption (Vecino et al., 2014; Douglas et al., 2016), coagulation (Zhu et al., 2016), photocatalytic oxidation (Chong et al., 2010), and biodegradation (Wu et al., 2010, 2011; Li et al., 2016). Unfortunately, their effectiveness in actual applications are frequently hampered by various factors (Oller et al., 2011) such as energy, efficiency, stability, and economy. Each approach 
has its own pros and cons, and none has the merits in all aspects. Nevertheless, scientists have never stopped looking for practices that can improve water treatment.

The combination of biodegradation and nanotechnology is suggested as a potential efficient, low-cost and environmental benign technique (Huang et al., 2014; Oh et al., 2016). Human has a long history of biological wastewater treatment by microorganisms. This worldwide approach has been proven as an effective and environmental-friendly strategy. The metabolic diversity of microorganisms ensures a variety of substrates to be consumed. Therefore, applications of bacteria such as Pseudomonas aeruginosa (Shukla et al., 2014), Aspergillus niger (Vassilev et al., 1997), and Rhodopseudomonas sphaeroides (Liu et al., 2015) in wastewater treatment have been investigated. It is well known by now that they can degrade toxic pollutants in aqueous media during their metabolisms. Amongst, photosynthetic bacteria (PSB) have been found as an effective and eco-friendly species that can simultaneously remove carbon, nitrogen and phosphorous in the synthetic sewage and soybean wastewater treatments (Nagadomi et al., 2000; Lu et al., 2010; Idi et al., 2015). On the other hand, limitations of biological wastewater treatment are apparent at the same time. Such biodegradation processes are usually slow. It is difficult to recover cells, and activities of recovered cells are significantly inhibited by substrates. Consequently, its application is greatly restricted.

The goal of our investigation is develop a system that couples biodegradation and nanotechnology with enhanced activity and stability of the biocatalyst, and with a desirable recycling property (Lenz et al., 2009; Li et al., 2015). Iron oxide nanoparticle (NP) has novel properties such as strong adsorption capacity, chemical inertness, high biocompatibility and superparamagnetism. Besides, NP amendment to enhance microbial metabolic activity has gained increased attentions in the recent years due to unique surface and quantum size effects of NP (Pan et al., 2010; Stone et al., 2010). These appealing features allow their applications as microbial immobilization carrier to enhance biocatalytic efficiency. For example, Xu et al. (2011) has successfully used iron oxide NP as a cell immobilization carrier with minimal mass transfer resistance. Gadhe et al. (2015) took advantage of NP's high electron transfer rate to boost microbial enzyme activity. Moreover, NP alone has been applied in contaminant controls. For example, inexpensive iron oxide NP has been employed as effective nanosorbents for the removal of a broad range of environmental contaminants such as metal ions (Liu et al., 2008) or dye (Iram et al., 2010). They have also been exploited as catalysts for the degradation of 4-chlorophenol (Xu and Wang, 2012). However, all these explorative endeavors face a common and major setback that, spontaneous aggregations in iron oxide NP solution quickly annihilate their function. To prevent aggregations from happening, one approach is to load NP onto carriers. Biochar is created from various biomass materials including agricultural and forestry residues through anaerobic pyrolysis. The large effective surface area, high porosity and abundant functional groups (Zhang et al., 2012) make it a perfect carrier for NP. Its wide application can also benefit from low cost, being eco-friendly, and most importantly, its ubiquitous availability. For example, Yao et al. (2013) has used biochar as an effective adsorbent in waste removal. Naturally, biochar is chosen as the most ideal carrier for iron oxide NP in our study.

Besides to find the features of $\mathrm{PSB} / \mathrm{NP} /$ biochar composite, another goal for our study is to develop a novel and effective technique in waste water treatment. We hope this composite can utilize advantages from individual components of, and a combination of, iron oxide NP (for adsorption, catalysis and magnetic separation), PSB (for biodegradation) and biochar (for adsorption). For these purposes, we first prepared multifunctional $\mathrm{Fe}_{3} \mathrm{O}_{4}$ /Biochar nanocomposites, followed by immobilizing PSB, R. capsulatus, onto their surfaces. The physical and chemical characterizations of $\mathrm{Fe}_{3} \mathrm{O}_{4} / \mathrm{Biochar}$, with and without $R$. capsulatus, were conducted. We measured products' capability in simultaneously removing chemical oxygen demand (COD), ammonia $\left(\mathrm{NH}_{4}^{+}\right)$, and phosphate $\left(\mathrm{PO}_{4}^{3-}\right)$ in aqueous solutions. Their regeneration property, one of the important characteristics for waste water treatment, was studied up to five recycles.

\section{MATERIALS AND METHODS}

\section{Bacteria Strain and Cultivations}

The strain of PSB bacteria, R. capsulatus, a purple non-sulfur bacterium, used in experiments was isolated in our laboratory and cultured in the medium containing purvate, yeast extract, $\mathrm{NaCl}$, $\mathrm{NH}_{4} \mathrm{Cl}, \mathrm{MgCl}_{2}$, and $\mathrm{K}_{2} \mathrm{HPO}_{4}$ at $\mathrm{pH} 7$ and $30^{\circ} \mathrm{C}$ under continuous illumination with incandescent lamps at a light intensity of about 2000 lux. All solutions were made up with sterile deionized water.

\section{Synthesis of $\mathrm{Fe}_{3} \mathrm{O}_{4} /$ Biochar}

Wheat straw was used to produce biochar through slow pyrolysis using a pyrolyzer at temperatures of $500^{\circ} \mathrm{C}$ continuously flushed with $\mathrm{N}_{2}$. And the temperature was maintained for $2 \mathrm{~h}$. Then the biochar was allowed to cool to room temperature, and sieved through a $0.15-\mathrm{mm}$ mesh. Then biochar was pretreated with $0.1 \mathrm{M} \mathrm{HNO}_{3}$ for $4 \mathrm{~h}$, washed with distilled water and then dried at room temperature. $\mathrm{Fe}_{3} \mathrm{O}_{4}$ NPs were synthesized by conventional chemical coprecipitation method (Molday, 1984). Briefly, a solution of $\mathrm{FeCl}_{3}$ and $\mathrm{FeSO}_{4}$ mixture (molar ratio 2:1) was prepared, followed by dropping enough aqueous $\mathrm{NH}_{4} \mathrm{OH}$ solution with vigorous stirring for 30 min under $\mathrm{N}_{2}$ protecting. The generated $\mathrm{Fe}_{3} \mathrm{O}_{4} \mathrm{NPs}$ were filtered and washed three times with distilled water by magnetic separation. The $\mathrm{Fe}_{3} \mathrm{O}_{4}$ /biochar was prepared as follows: the obtained $\mathrm{Fe}_{3} \mathrm{O}_{4}$ (about $0.5 \mathrm{~g}$ ) were diluted to $500 \mathrm{~mL}$ deionized water. Subsequently, $2 \mathrm{~g}$ biochar were introduced to the $\mathrm{Fe}_{3} \mathrm{O}_{4}$ suspension and the mixture was stirred for $4 \mathrm{~h}$ at room temperature. The $\mathrm{Fe}_{3} \mathrm{O}_{4} /$ biochar composite obtained was washed immediately with distilled water for five times by magnetic separation and dried in an oven at $80^{\circ} \mathrm{C}$ for $6 \mathrm{~h}$.

The products were characterized by field emission gun scanning electron microscopy (SEM, JEOL, JSM-5610LV) and transmission electron microscopy (TEM, JEOL, JEM-200CX). For TEM analysis, $5 \mu \mathrm{L}$ sample was placed onto a carbon-coated copper grid and allowing the solvent to evaporate in air. 
The crystal structures were determined using X-ray diffraction (XRD) (Shimadzu XD -3A). The patterns with the $\mathrm{Cu}$ Karadiation $(k=1.54051 \AA)$ at a generator voltage of $40 \mathrm{kV}$ and current of $40 \mathrm{~mA}$ were recorded in the region of $2 \theta$ from $10^{\circ}$ to $70^{\circ}$. Brunauer-Emmett-Teller (BET) surface area of the samples was determined by using a computer-controlled nitrogen gas adsorption analyzer (Quantachrome-NOVA4000e). FTIR spectra of the materials were recorded with $\mathrm{KBr}$ disks in the range of 4000-400 $\mathrm{cm}^{-1}$ on Nicolet Magna FTIR-750 spectrometer. The zeta potential $(\zeta)$ of the $\mathrm{Fe}_{3} \mathrm{O}_{4} \mathrm{NP}$ and $\mathrm{Fe}_{3} \mathrm{O}_{4}$ /biochar was measured with a zeta potential analyzer (BECKMAN, Delsa 440SX).

\section{Immobilization of Bacteria with $\mathrm{Fe}_{3} \mathrm{O}_{4} /$ Biochar Composite}

The PSB, R. capsulatus, was cultivated in medium for $72 \mathrm{~h}$ at $30^{\circ} \mathrm{C}$. Cells were harvested at the mid-log phase of the growth curve, as shown by an optical density of $0.3-0.5$ at $600 \mathrm{~nm}$ $\left(\mathrm{OD}_{600}\right)$, by centrifugation $(5000 \mathrm{rpm})$ at $4^{\circ} \mathrm{C}$ for $10 \mathrm{~min}$. The collected bacteria were washed five times with distilled water and then re-suspended in distilled water. Then $1 \mathrm{~g}$ magnetic $\mathrm{Fe}_{3} \mathrm{O}_{4}$ /biochar was mixed with $1 \mathrm{~g}$ cell (wet weight) in $500 \mathrm{~mL}$ culture solution. In order to make the $\mathrm{Fe}_{3} \mathrm{O}_{4}$ /biochar and cells contact sufficiently, the flask was placed in the shaker for $2 \mathrm{~h}$ at $30^{\circ} \mathrm{C}$ until cells adsorbed on the surface and pores of $\mathrm{Fe}_{3} \mathrm{O}_{4}$ /biochar. A permanent magnet was applied to the flask, separating the immobilized biomass from mixture. The immobilized cells were washed gently two times with distilled water to remove free cells. Bacteria supported on $\mathrm{Fe}_{3} \mathrm{O}_{4}$ /biochar so obtained were used to study the nutrient $\left(\mathrm{COD}, \mathrm{NH}_{4}^{+}\right.$, and $\mathrm{PO}_{4}^{3-}$ ) removal in water.

The surface morphologies of $\mathrm{Fe}_{3} \mathrm{O}_{4}$ /biochar supported $R$. capsulatus were determined by SEM. The amount of PSB cells on $\mathrm{Fe}_{3} \mathrm{O}_{4}$ /biochar were measured by qPCR assays. Genomic DNA was subsequently extracted using bacterial DNA kit (Omega), following the manufacturer's instruction. The copy numbers of pufM gene were quantified by real-time qPCR analysis $\left(\mathrm{C} 1000^{\mathrm{TM}}\right.$ Thermal Cycler equipped with $\mathrm{CFX} 96^{\mathrm{TM}}$ Real-Time system) using primer pufM.557F/750R (Feng et al., 2014). The qPCR standard curve was generated as described by Feng et al. (2011). The $25 \mu \mathrm{L}$ reaction mixture contained $12.5 \mu \mathrm{L}$ of SYBR Premix Ex Taq ${ }^{\mathrm{TM}}, 0.5 \mu \mathrm{M}$ of each primer, $0.5 \mu \mathrm{L}$ of BSA at $20 \mathrm{mg} / \mathrm{mL}$ initial concentration, and $1.0 \mu \mathrm{L}$ template containing approximately $2-9 \mathrm{ng}$ DNA. Same procedure was carried out for a blank of using water as the template. The amplicons were confirmed by agarose gel electrophoresis of qPCR amplicons of the puf $\mathrm{M}$ gene and the melting curve analysis always resulted in a single peak. Real-time PCR was performed in triplicate, and the high amplification efficiencies of $97.4-104 \%$ were obtained with high consistency $R^{2}$ values of $0.976-0.997$.

\section{Nutrient Removal Efficiency}

For the treatment experiment, the chemical composition of the synthetic wastewater was as follows: glucose, $\mathrm{NH}_{4} \mathrm{Cl}, \mathrm{KH}_{2} \mathrm{PO}_{4}$, $\mathrm{MgSO}_{4} \cdot 7 \mathrm{H}_{2} \mathrm{O}, \mathrm{NaHCO}_{3}, \mathrm{CaCl}_{2} \cdot 2 \mathrm{H}_{2} \mathrm{O}$. The initial COD, $\mathrm{NH}_{4}-\mathrm{N}$, and TP of the wastewater were $877 \mathrm{mg} / \mathrm{L}, 29.7 \mathrm{mg} / \mathrm{L}$, and
$3.6 \mathrm{mg} / \mathrm{L}$, respectively. Batch experiments were carried out in a $250 \mathrm{~mL}$ Erlenmeyer flask as bio-reactor at room temperature with a light intensity of 2000 lux.

The $\mathrm{Fe}_{3} \mathrm{O}_{4}$ /biochar composite $(0.1 \mathrm{~g})$, free cells (the same amount of immobilized) and $\mathrm{PSB} / \mathrm{Fe}_{3} \mathrm{O}_{4}$ /biochar [immobilized PSB (approx. $0.05 \mathrm{~g}$ wet weight) and $\mathrm{Fe}_{3} \mathrm{O}_{4}$ /biochar $(0.05 \mathrm{~g}$ )] were mixed with $100 \mathrm{~mL}$ synthetic wastewater, respectively. The wastewater without any agents was set as control. Then, the suspension was sampled from the bioreactors by magnetic separation at different periods. The supernatant was filtered through a $0.45 \mu \mathrm{m}$ membrane filter to test the concentrations of nutrient including $\mathrm{COD}, \mathrm{NH}_{4}^{+}$, and $\mathrm{PO}_{4}^{3-}$. $\mathrm{COD}$ was measured using a COD analyzer (DR1010 COD, HACH, China). The phosphate concentrations in the samples were analyzed by molybdenum blue spectrophotometric method (Shimadzu spectrophotometer UV-3150PC). The concentrations of $\mathrm{NH}_{4}^{+}$ were determined by the Nessler reagent colorimetric method. The numbers of PSB during nutrient removal were measured by qPCR.

Upon completion of the wastewater reduction process, the cells were recovered by magnetic separation, and then washed three times by deionized water. The fresh wastewater was added to the flask in consecutive degradation processes to test the reusability of $\mathrm{PSB} / \mathrm{Fe}_{3} \mathrm{O}_{4} /$ biochar agent under the same conditions. Each experiment was conducted in triplicate.

\section{Statistical Analysis}

Statistical procedures were performed with the SPSS 13.0 software package for Windows. All the experiments were done in triplicate, and the data were expressed as the means with standard deviation (SD). The significance of the difference between the treatments means was assessed by Tukey's multiple range tests. Differences at $P<0.05$ were considered statistically significant.

\section{RESULTS AND DISCUSSION}

\section{Characteristics of $\mathrm{Fe}_{3} \mathrm{O}_{4} /$ Biochar Nanocomposite and Immobilized R. capsulatus}

Figure 1 illustrates our product preparation process. Biochar prepared from biomass pyrolysis has a large surface area. It provides numerous functional groups for $\mathrm{Fe}_{3} \mathrm{O}_{4}$ NPs to tether at. A good mixing ensures the formation of $\mathrm{Fe}_{3} \mathrm{O}_{4}$ /biochar nanocomposite. To characterize their morphologies, we collected and compared $\mathrm{X}$-ray diffraction patterns of $\mathrm{Fe}_{3} \mathrm{O}_{4}$, biochar and $\mathrm{Fe}_{3} \mathrm{O}_{4}$ /biochar (Figure 2A). Main diffraction peaks for the $\mathrm{Fe}_{3} \mathrm{O}_{4}$, corresponding to the (220), (311), (400), (422), (511), and (440) planes, match well with crystalline cubic $\mathrm{Fe}_{3} \mathrm{O}_{4}$ (JCPDS: 65-3107). All these peaks appear again in the spectrum for $\mathrm{Fe}_{3} \mathrm{O}_{4}$ /biochar nanocomposite, suggesting the crystal structure of $\mathrm{Fe}_{3} \mathrm{O}_{4}$ is retained. Crystalline $\mathrm{Fe}_{3} \mathrm{O}_{4}$ are in both samples, indicated by the strong and sharp peaks. The peak at $26.2^{\circ}$ is present in both biochar and nanocomposite. Its relatively high intensity and symmetry are a result of graphitization. 


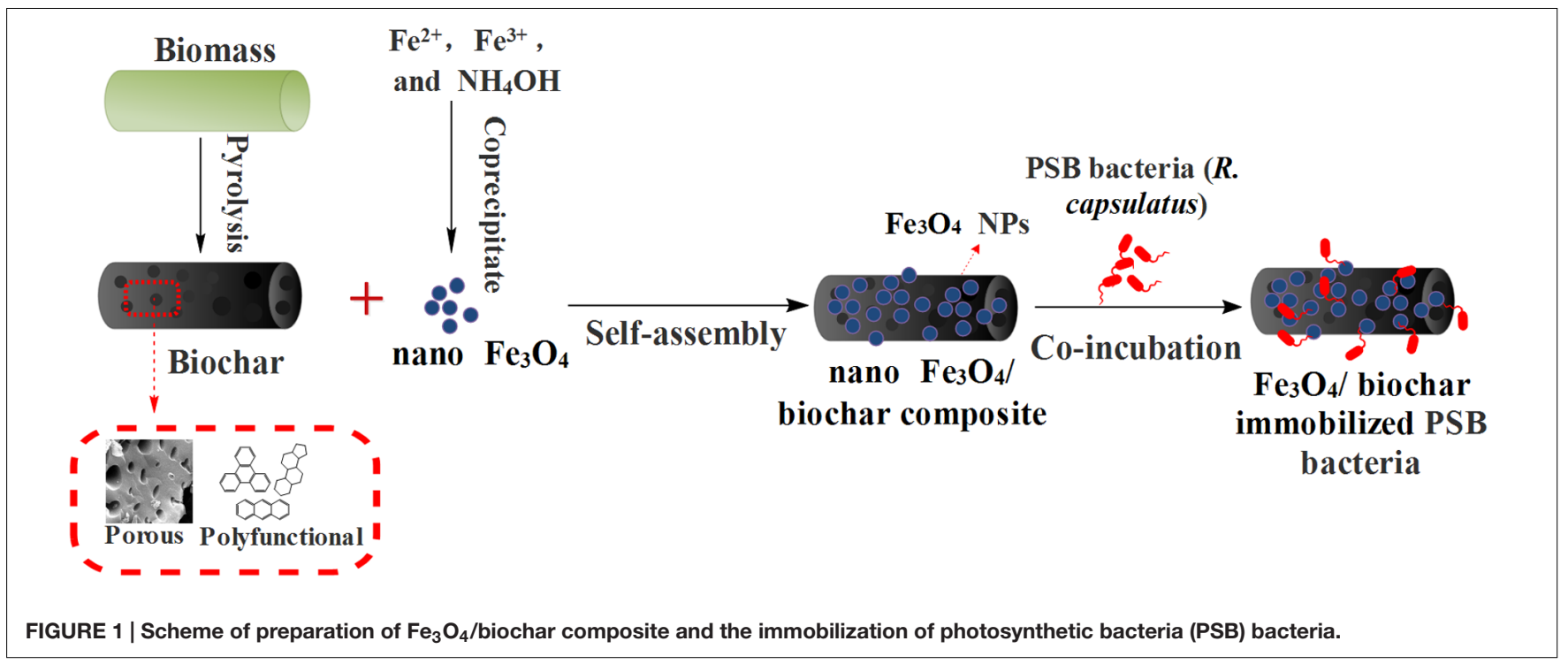

A

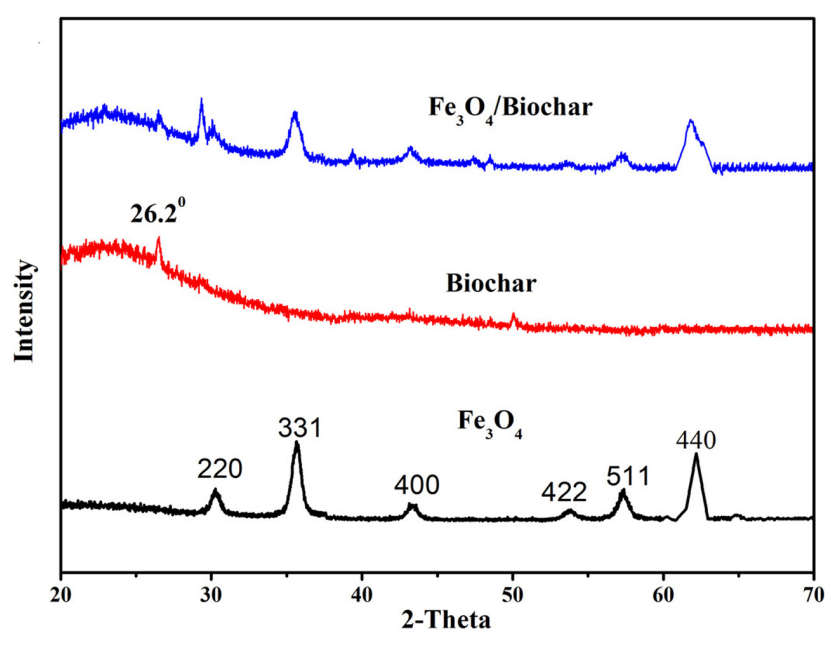

B

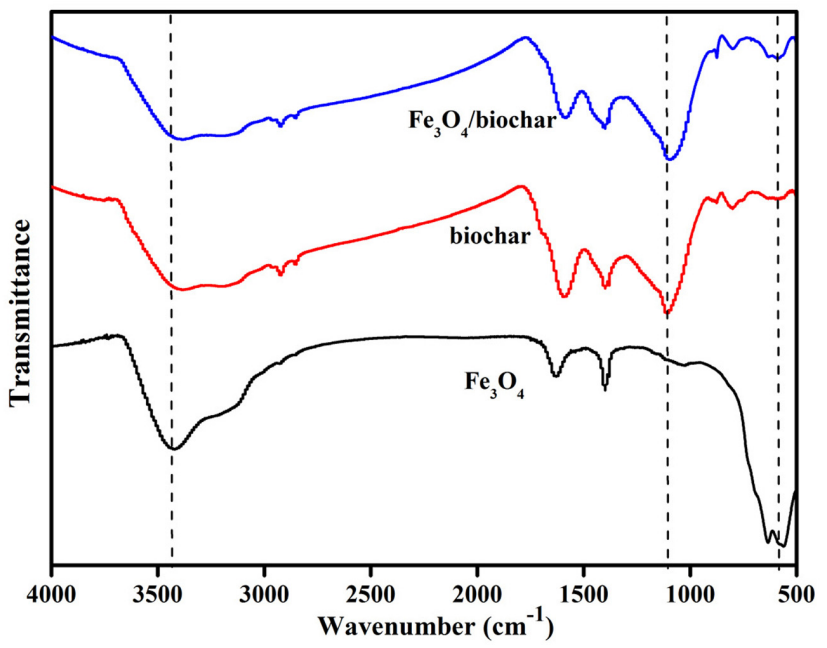

FIGURE 2 | (A) X-ray diffraction (XRD) patterns and (B) FTIR spectra of $\mathrm{Fe}_{3} \mathrm{O}_{4}$, biochar, and $\mathrm{Fe}_{3} \mathrm{O}_{4} /$ biochar.

Furthermore, the broad band at $20-30^{\circ}$ indicates that majority of biochar remains as amorphous in the nanocomposite.

Studies of $\mathrm{Fe}_{3} \mathrm{O}_{4} \mathrm{NP}$ adsorption onto different materials have been reported. Due to the intrinsic nature of biochar, $\mathrm{Fe}_{3} \mathrm{O}_{4}$ particles can adsorbed to the biochar FTIR has been a useful tool to confirm the adsorption. We collected FTIR spectra for $\mathrm{Fe}_{3} \mathrm{O}_{4}$ NP, biochar, and $\mathrm{Fe}_{3} \mathrm{O}_{4} /$ biochar nanocomposite (Figure 2B). The spectrum for nanocompsite largely resembles that for biochar. However, the key peak at $636 \mathrm{~cm}^{-1}$, ascribed to Fe-O stretching, is observed in the nanocomposite spectrum. This observation reflects the presence of iron oxide in the composite.

We examined the morphology and size of the obtained materials with TEM and SEM techniques. TEM image of $\mathrm{Fe}_{3} \mathrm{O}_{4}$ shows that these NPs are spherical, with an average diameter of $10 \pm 2.5 \mathrm{~nm}$ (Figure 3a). With SEM images, we found the surfaces of biochar are rough and porous (Figure 3d), providing large contact surfaces to for $\mathrm{Fe}_{3} \mathrm{O}_{4}$ particles to deposit onto. $\mathrm{Fe}_{3} \mathrm{O}_{4}$ particles are uniformly dispersed with very little aggregation in TEM (Figures $\mathbf{3 b}, \mathbf{c}$ ) and SEM (Figures 3e,f) images.

The data of BET surface area, pore size diameters and pore volume of the materials were measured and presented in Table 1. The specific surface area of the as-prepared $\mathrm{Fe}_{3} \mathrm{O}_{4} /$ biochar was $114.85 \mathrm{~m}^{2} / \mathrm{g}$. It is interesting to notice this area is close to the sum of areas for $\mathrm{Fe}_{3} \mathrm{O}_{4}\left(67.12 \mathrm{~m}^{2} / \mathrm{g}\right)$ and for biochar $\left(42.08 \mathrm{~m}^{2} / \mathrm{g}\right)$. Nevertheless, the greatly increased surface area proves the $\mathrm{Fe}_{3} \mathrm{O}_{4}$ are tethered onto biochar surfaces.

An increased surface area of $\mathrm{Fe}_{3} \mathrm{O}_{4} /$ biochar nanocomposite accommodates abundant active sites for bacteria to attach onto as shown in Figure 1. We measured the amount of 


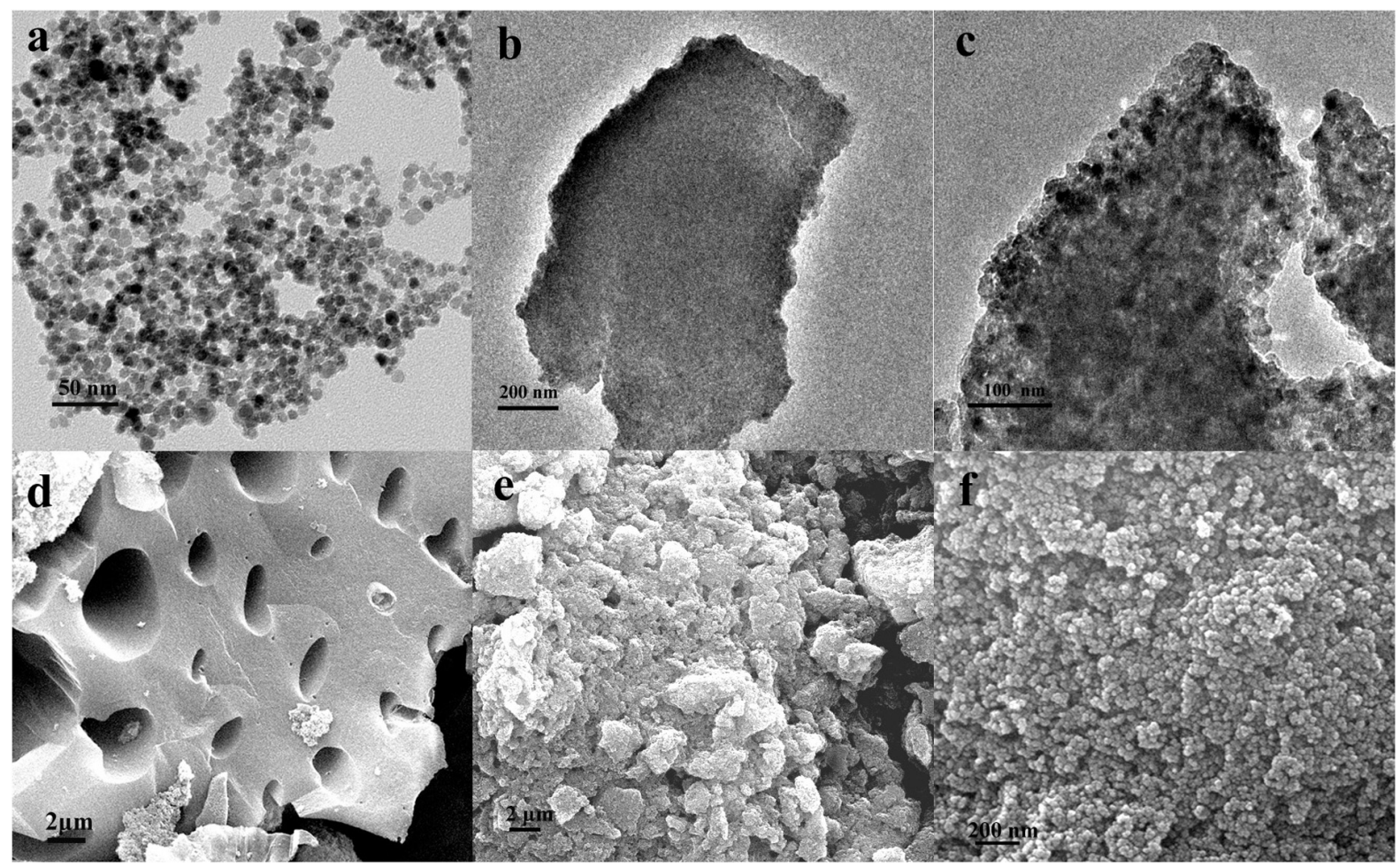

FIGURE 3 | TEM micrographs of (a) $\mathrm{Fe}_{3} \mathrm{O}_{4}$ nanoparticles (NPS), (b) biochar, and (c) $\mathrm{Fe}_{3} \mathrm{O}_{4} /$ biochar, $\mathrm{SEM}$ images of (d) biochar, (e) Fe $3 \mathrm{O}_{4} /$ biochar, and (f) magnified SEM image of $\mathrm{Fe}_{3} \mathrm{O}_{4} /$ biochar.

immobilized bacteria with qPCR. As shown in Figure 4A, the $\mathrm{Fe}_{3} \mathrm{O}_{4}$ /biochar exhibits an excellent adsorption performance on PSB. The adsorption is fast, and the efficiency plateaus at about $90 \%$ after $30 \mathrm{~min}$ of incubation. Its adsorption capacity is found to be approximately $5.45 \times 10^{9}$ cells $/ g$. SEM images show that cells are adsorbed onto the surface of $\mathrm{Fe}_{3} \mathrm{O}_{4}$ /biochar composite, and the morphologies of immobilized bacteria appear to remain unchanged (Figure 4B). We believe the exceptional adsorption phenomenon roots from several reasons. First, $\mathrm{Fe}_{3} \mathrm{O}_{4}$ /biochar nanocomposite offers a larger specific surface area, higher surface energy, and hence more accessible active sites. When these factors are combined, it is not a surprise that this nanocomposite has an increased efficiency in the microbial cells adsorption. Secondly, electrostatic interactions play a facilitating role in adsorption. The outer membrane of PSB cell wall consists of negatively charged lipopolysaccharides and phosphate. At the same time, the zeta potential values of $\mathrm{Fe}_{3} \mathrm{O}_{4}$ and $\mathrm{Fe}_{3} \mathrm{O}_{4}$ /biochar were 14.8 and $4.2 \mathrm{mV}$, respectively, suggesting their surfaces is mostly positively charged. Strong electrostatic attractions ensure an enhancement in the adsorption. Moreover, the adsorption is facilitated by the hydrophobic interactions between constituents of bacteria (e.g., proteins, lipopolysaccharides, mycolic acid, and etc) and surface of biochar.

Having magnetic $\mathrm{Fe}_{3} \mathrm{O}_{4}$ in the final product leads to an important feature that distinguishes it from other similar products. When placed next to a magnetic bar, the $\mathrm{Fe}_{3} \mathrm{O}_{4} /$ biochar
TABLE 1 | Brunauer-Emmett-Teller (BET) analysis of biochar, $\mathrm{Fe}_{3} \mathrm{O}_{4}$, and $\mathrm{Fe}_{3} \mathrm{O}_{4} /$ biochar.

\begin{tabular}{lccc}
\hline Samples & Biochar & $\mathbf{F e}_{\mathbf{3}} \mathbf{O}_{\mathbf{4}}$ & $\mathbf{F e}_{\mathbf{3}} \mathbf{O}_{\mathbf{4}} \mathbf{\text { biochar }}$ \\
\hline Specific surface area $\left(\mathrm{m}^{2} / \mathrm{g}\right)$ & 42.08 & 67.12 & 114.85 \\
Pore size diameters $(\mathrm{nm})$ & 4.34 & - & 5.78 \\
Pore volume $\left(\mathrm{cm}^{3} / \mathrm{g}\right)$ & 0.27 & - & 0.39
\end{tabular}

with immobilized PSB can be easily separated by the external magnetic field (insert of Figure 4B). This feature allows an extremely convenient, and more importantly, non-destructive, separation method for this product. A wide range of applications can take advantage of this feature by using $\mathrm{Fe}_{3} \mathrm{O}_{4}$ /biochar nanocomposite as the support for PSB.

\section{Nutrient Removal}

We developed the $\mathrm{Fe}_{3} \mathrm{O}_{4}$ /biochar nanocomposite, as well as the subsequent $\mathrm{PSB} / \mathrm{Fe}_{3} \mathrm{O}_{4} /$ biochar composite, for water treatment. Therefore, their efficiencies in being sorbent and/or catalyst were evaluated in our study. The results are presented below.

\section{Removal of COD}

It is well known that PSB can catabolize organic species through photophosphorylation by utilizing light as the additional energy source. After $30 \mathrm{~h}$ of treatment, $62 \%$ of COD in synthetic wastewater were removed by free PSB bacteria 

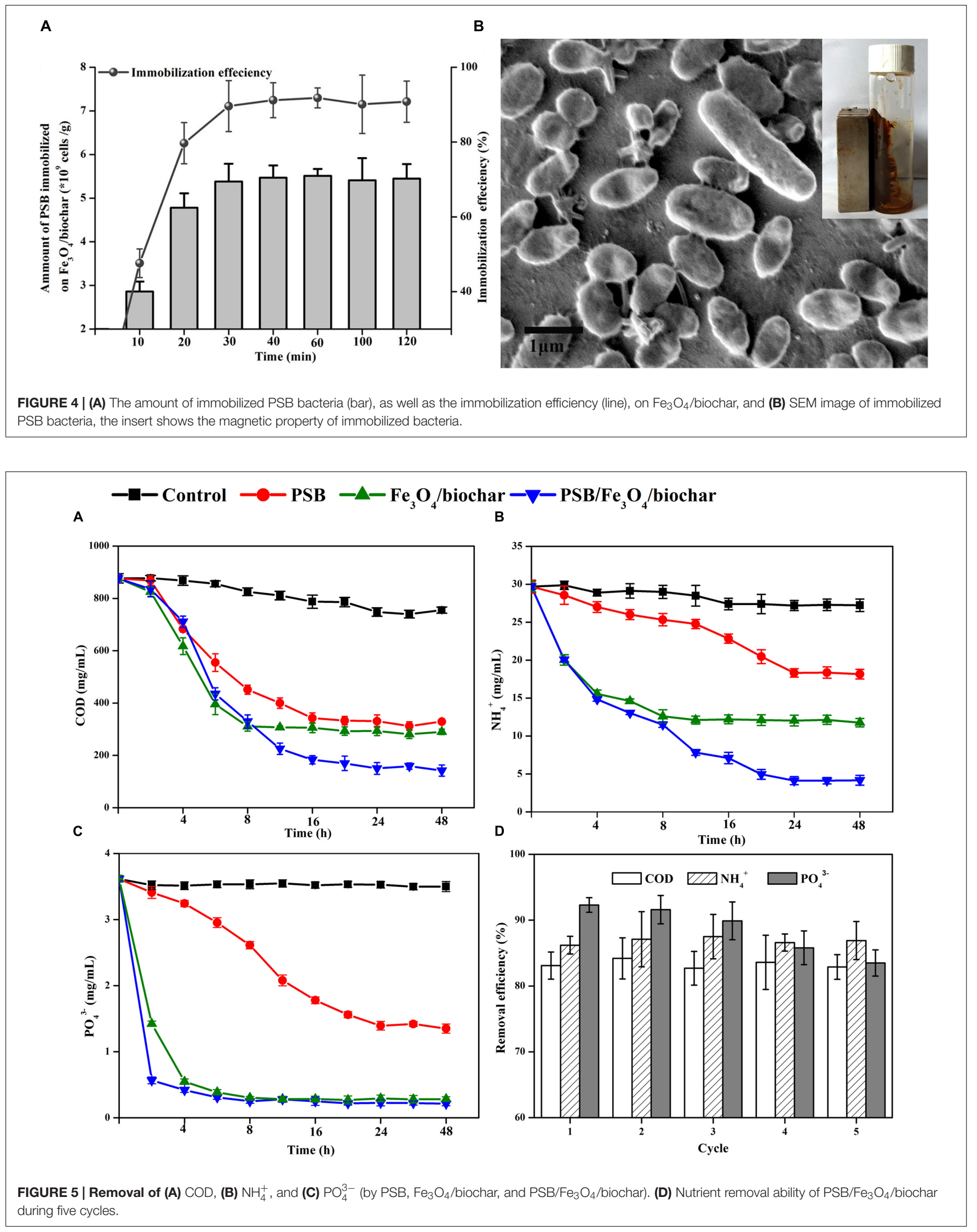


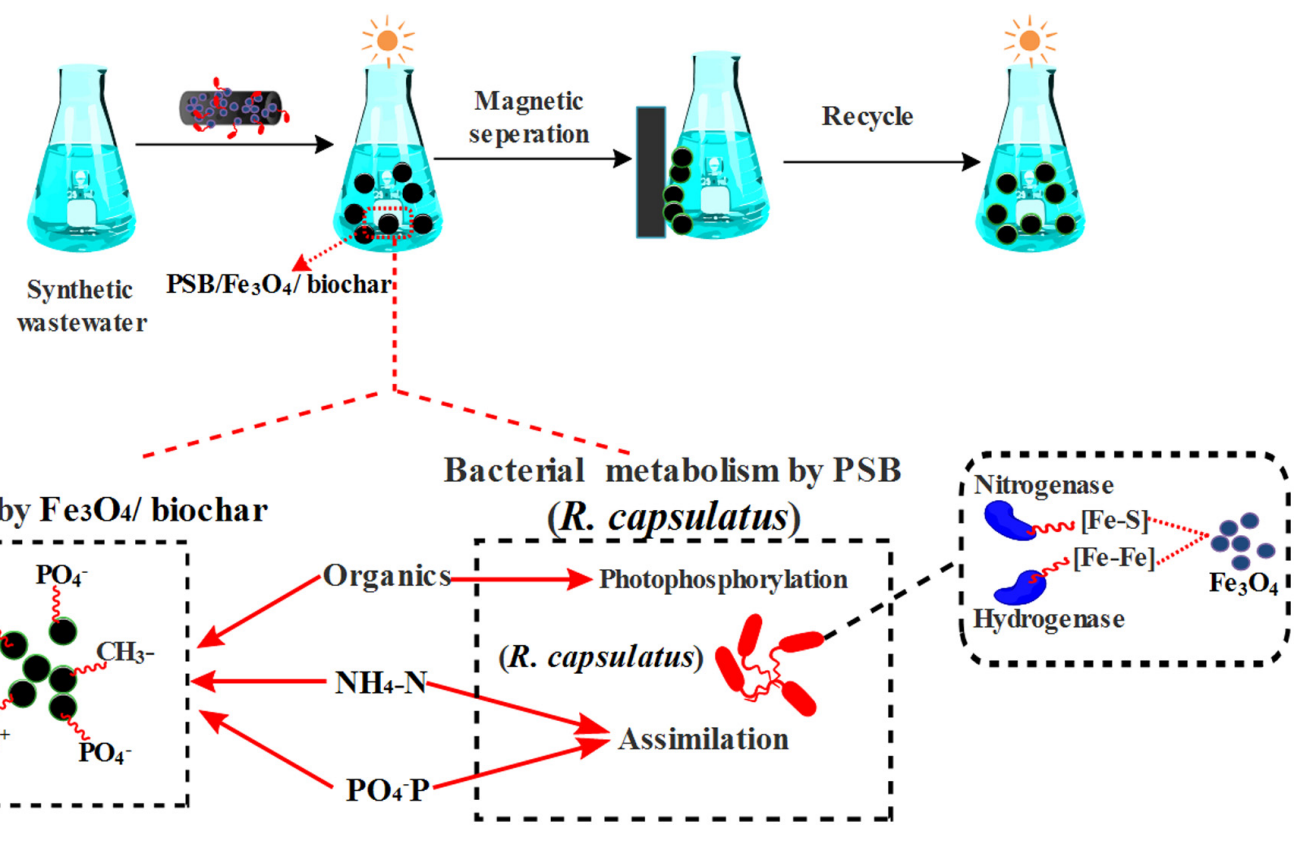

FIGURE 6 | Possible nutrient removal mechanisms by the $\mathrm{PSB} / \mathrm{Fe}_{3} \mathrm{O}_{4} /$ biochar.

(Figure 5) The narrow 2.2-eV band gap of $\mathrm{Fe}_{3} \mathrm{O}_{4} \mathrm{NPs}$ (Akhavan and Azimirad, 2009) makes them effective photocatalysts for absorbing visible light. The $\mathrm{Fe}_{3} \mathrm{O}_{4} /$ biochar nanocomposite has a high mesopore volume, a larger surface area and multiple sites for PSB adsorption. Because of such properties that favor adsorption and light degradation, $\mathrm{Fe}_{3} \mathrm{O}_{4} /$ biochar nanocomposite $(0.1 \mathrm{~g})$ exhibits $67 \%$ COD removal. When PSB (approximately $0.05 \mathrm{~g}$ ) are immobilized onto such nanocomposite $(0.05 \mathrm{~g})$, COD removal efficiency is boosted to $83 \%$. This represents a ca. $50 \%$ enhancement, compared to $\mathrm{PSB}$ only, or $\mathrm{Fe}_{3} \mathrm{O}_{4} /$ biochar nanocomposite only. This $\mathrm{Fe}_{3} \mathrm{O}_{4} /$ biochar nanocomposite performs a better efficiency on COD removal than that of constructed wetlands methods ( $65 \%$ COD) (Wang et al., 2016) and has a similar removal efficiency as the active sludge system does (60-90\% COD) (Nagadomi et al., 2000; Eldyasti et al., 2011). A proposed mechanism for this enhancement is illustrated in Figure 6. First, the PSB R. capsulatus is tightly trapped on the $\mathrm{Fe}_{3} \mathrm{O}_{4} /$ biochar composite with high capacity and stability. Immobilized bacteria can enhance their physical characteristics, which results in promoting mass transfer of substrate from the environment to the central reaction site. Secondly, Iron oxide NP could facilitate the bacterial bioactivity and metabolite due to their unique surface and quantum size effects. The energy plays a very important role in microbe's capability in the degradation of organic pollutants. Nitrogenase and hydrogenase are the key enzymes in energy metabolism of PSB (Khusnutdinova et al., 2012; Lo et al., 2012). Due to the presence of [Fe-S] and $[\mathrm{Fe}-\mathrm{Fe}]$ at the active sites of the nitrogenase and hydrogenase, respectively, an addition of $\mathrm{Fe}_{3} \mathrm{O}_{4} \mathrm{NP}$ can improve their enzymatic activities. By coupling the $\mathrm{Fe}^{2+} / \mathrm{Fe}^{3+}$ redox pair with the bacterial oxidation/reduction reactions, the $\mathrm{Fe}_{3} \mathrm{O}_{4} \mathrm{NP}$ will speed up the electron transfer rates. Such observations have been reported by Gadhe et al. (2015), in which authors found iron oxide NP promoted biohydrogen recovery from dairy wastewater. Another study was reported that such NP facilitated methanogenesis by enabling direct interspecies electron transfer in syntrophic methane production (Jiang et al., 2013). Our previous investigations ( $\mathrm{He}$ et al., 2016) have $\mathrm{Fe}_{3} \mathrm{O}_{4} \mathrm{NP}$ can promote the growth, metabolism and enzyme activities of bacteria. Moreover, $\mathrm{Fe}_{3} \mathrm{O}_{4}$ can act as extracellular electron acceptors to efficiently scavenge reducing equivalents, thus are speculated to be able to stimulate the growth and metabolisms of PSB (Kato et al., 2012). In addition, a small quantity of iron ions are gradually released into environment by $\mathrm{Fe}_{3} \mathrm{O}_{4}$ NP. Using ICP-OE, we detected $\sim 10 \mu \mathrm{g} / \mathrm{ml} \mathrm{Fe}^{3+}$ in $\mathrm{Fe}_{3} \mathrm{O}_{4}$ NP-saturated wastewater after 3 days (Supplementary Figure 1). The presence of iron ions can stimulate the growth and metabolism of PSB, thus improves the COD removal.

\section{Removal of $\mathrm{N}$ and $\mathrm{P}$}

Our study clearly shows the combination of $\mathrm{Fe}_{3} \mathrm{O}_{4} /$ biochar and PSB can enhance the removal of $\mathrm{NH}_{4}^{+}$and $\mathrm{PO}_{4}^{3-}$ as well. $\mathrm{N}$ and $\mathrm{P}$ are essential nutrients for bacteria growth and they play an important role in substance and energy metabolisms. $\mathrm{NH}_{4}^{+}$can be assimilated by almost all PSB to synthesize proteins or other organic biomass species. Phosphorous can be readily accumulated in PSB cells as polyphosphate (poly-P) (Wang et al., 2014). Therefore, it is not unexpected to find PSB-only treatment removes $61 \% \mathrm{NH}_{4}^{+}$and $63 \% \mathrm{PO}_{4}^{3-}$ (Figures 5B,C).

The $\mathrm{Fe}_{3} \mathrm{O}_{4}$ /biochar nanocomposite demonstrates a significant enhancement in the $\mathrm{PO}_{4}^{3-}$ removal $(P<0.05)$ (Figure 5C). Not only does the removal efficiency almost reach $100 \%$, but 
also the time needed for the maximum removal is significantly shortened $(P<0.05)$. More than $92 \%$ of phosphates are removed by the nanocomposite within $20 \mathrm{~min}$. The high efficiency of $\mathrm{Fe}_{3} \mathrm{O}_{4} \mathrm{NP}$ in phosphate removal is attributed to their larger surface areas and surface hydroxide groups (Lalley et al., 2016). Phosphate ions can be absorbed on the NP's magnetite surface, followed by diffusion into their interior pores. Electrostatic interaction between the positively charged $\mathrm{Fe}_{3} \mathrm{O}_{4}$ surface and negatively charged phosphate ion plays the major role in the adsorption. In addition, $\mathrm{PO}_{4}^{3-}$ can replace hydroxyl ions on the NP surface (Chen et al., 2016) and form inner-sphere complexes, including monodentate, bidentate, mono-nuclear or binuclear complexes. Compared to phosphate, the adsorption capacity of $\mathrm{Fe}_{3} \mathrm{O}_{4} /$ biochar for $\mathrm{NH}_{4}^{+}$is relatively low. This is mostly due to the repulsive electrostatic interaction between $\mathrm{Fe}_{3} \mathrm{O}_{4}$ surfaces and $\mathrm{NH}_{4}^{+}$. At equilibrium, only about $52 \%$ of $\mathrm{NH}_{4}^{+}$are removed by $\mathrm{Fe}_{3} \mathrm{O}_{4}$ /biochar nanocomposite.

When PSB are immobilized onto $\mathrm{Fe}_{3} \mathrm{O}_{4} /$ biochar nanocomposite, the final composite product has an even higher performance in $\mathrm{N}$ and $\mathrm{P}$ removal $(P<0.05)$. In our experiments, $94 \%$ of $\mathrm{PO}_{4}^{3-}$ and $86 \%$ of $\mathrm{NH}_{4}^{+}$were removed from the wastewater. This outcome indicates that this $\mathrm{Fe}_{3} \mathrm{O}_{4} /$ biochar nanocomposite has a higher $\mathrm{NH}_{4}^{+}$removal efficiency than the constructed wetlands methods $\left(\sim 46 \% \mathrm{NH}_{4}^{+}\right)$(Wang et al., 2016) and a better $\mathrm{PO}_{4}^{3-}$ removal efficiency than the active sludge (67-70\%) (Vaiopoulou and Aivasidis, 2008; Eldyasti et al., 2011).

The abundances of PSB immobilized onto $\mathrm{Fe}_{3} \mathrm{O}_{4}$ /biochar during nutrient removal were quantified by qPCR. As shown in Supplementary Figure 2, the quantity of immobilized PSB increases by $\sim 10 \%$ after the wastewater treatment. This finding suggests that nutrients in wastewater could stimulate the PSB immobilization, an indirect proof for the synergy of PSB and $\mathrm{Fe}_{3} \mathrm{O}_{4}$ /biochar. Undoubtedly, the higher amount of immobilized PSB eventually leads to an increase in the nutrients removal elevated consuming quantity of organics, ammonia, and phosphate that can be used for bacterial growth. The growth of cells could be beneficial to the bioremediation of wastewater.

\section{Reusability of $\mathrm{PSB} / \mathrm{Fe}_{3} \mathrm{O}_{4} / \mathrm{Biochar}$ Composites}

Another important property for an ideal wastewater treatment is the recyclability of biocatalyst. Two crucial questions need to be asked: can it be easily recovered, and does the recycled catalyst maintain its activity? The $\mathrm{PSB} / \mathrm{Fe}_{3} \mathrm{O}_{4} /$ biochar composite excels in both aspects. First, benefited from the magnetism of iron oxide, this composite it can be easily recovered by a magnet bar. $\mathrm{Fe}_{3} \mathrm{O}_{4} \mathrm{NP}$ has the magnetic property. Magnetism is a unique physical property that independently helps in water purification by influencing the physical properties of contaminants in water. Adsorption procedure combined with magnetic separation has therefore been used extensively in water treatment and environmental cleanup (Xu et al., 2012). For example, $\mathrm{Fe}_{3} \mathrm{O}_{4}$ hollow nanospheres were shown to be an effective sorbent for red dye (Iram et al., 2010). The saturation magnetization of prepared nanospheres was observed to be $42 \mathrm{emu}^{-1}$, which was sufficient for magnetic separation with a magnet (critical value at $16.3 \mathrm{emu} \mathrm{g}^{-1}$ ). Secondly, the recycled composite does not lose its activity. We measured the nutrient removal capabilities of $\mathrm{PSB} / \mathrm{Fe}_{3} \mathrm{O}_{4} /$ biochar composite for up to five recycles (Figure 5D). Consistent COD (steadily at $83 \%)$ and $\mathrm{NH}_{4}^{+}(86-88 \%)$ removal efficiencies are observed throughout these cycles. Although its efficiency in $\mathrm{PO}_{4}^{3-}$ removal gradually decreases from $94 \%$ in cycle- 1 to $88 \%$ in cycle- 5 , the $\mathrm{PSB} / \mathrm{Fe}_{3} \mathrm{O}_{4} /$ biochar composite remains as a very effective $\mathrm{PO}_{4}^{3-}$ removal agent. As we discussed above, the amount of immobilized PSB increases upon wastewater treatment. Undoubtedly, this is one of the reasons why the composite maintains its high nutrient removal efficiency. Based on these findings, it is clear that $\mathrm{PSB} / \mathrm{Fe}_{3} \mathrm{O}_{4} /$ biochar composite is an ideal agent for wastewater treatment.

\section{CONCLUSION}

In this study, we prepared $\mathrm{Fe}_{3} \mathrm{O}_{4}$ /biochar nanocomposite by the self-assembly method. The $\mathrm{Fe}_{3} \mathrm{O}_{4}$ were well dispersed on the biochar with little aggregation. Subsequently, PSB were immobilized onto it to produce the final $\mathrm{PSB} / \mathrm{Fe}_{3} \mathrm{O}_{4} /$ biochar composite product. Our results demonstrate this composite possesses excellent properties for an ideal agent for practical wastewater treatments. Its nutrient (COD, N, and $\mathrm{P}$ ) removal efficiencies remain high even after five cycles. Its magnetic property enables an easy recovery at the end of each cycle. Besides water treatment, we believe its application may also be expanded to the biodegradation of other hazardous compounds in environment.

\section{AUTHOR CONTRIBUTIONS}

SH and LY designed and conducted the experiments. JD, YF, and BY analyzed the data. SH, LZ, and LY wrote the paper.

\section{ACKNOWLEDGMENTS}

This work was supported by grants from the National Natural Science Foundation of China (grant numbers 41301267, 41371255, and 31300705). We also acknowledge financial support by Special Fund for Agro-scientific Research in the Public Interest (201503106).

\section{SUPPLEMENTARY MATERIAL}

The Supplementary Material for this article can be found online at: http://journal.frontiersin.org/article/10.3389/fmicb. 2017.00823/full\#supplementary-material 


\section{REFERENCES}

Akhavan, O., and Azimirad, R. (2009). Photocatalytic property of Fe2O3 nanograin chains coated by $\mathrm{TiO}_{2}$ nanolayer in visible light irradiation. Appl. Catal. A Gen. 369, 77-82. doi: 10.1016/j.apcata.2009.09.001

Beaver, J. R., Manis, E. E., Loftin, K. A., Graham, J. L., Pollard, A. I., and Mitchell, R. M. (2014). Land use patterns, ecoregion, and microcystin relationships in U.S. lakes and reservoirs: a preliminary evaluation. Harmful Algae 36, 57-62. doi: 10.1016/j.hal.2014.03.005

Chen, J., Yan, L. G., Yu, H. Q., Li, S., Qin, L. L., Liu, G. Q., et al. (2016). Efficient removal of phosphate by facile prepared magnetic diatomite and illite clay from aqueous solution. Chem. Eng. J. 287, 162-172. doi: 10.1016/j.cej.2015.11.028

Chong, M. N., Jin, B., Chow, C. W. K., and Saint, C. (2010). Recent developments in photocatalytic water treatment technology: a review. Water Res. 44, 2997-3027. doi: 10.1016/j.watres.2010.02.039

Douglas, G. B., Lurling, M., and Spears, B. M. (2016). Assessment of changes in potential nutrient limitation in an impounded river after application of lanthanum-modified bentonite. Water Res. 97, 47-54. doi: 10.1016/j.watres. 2016.02.005

Eldyasti, A., Andalib, M., Hafez, H., Nakhla, G., and Zhu, J. (2011). Comparative modeling of biological nutrient removal from landfill leachate using a circulating fluidized bed bioreactor (CFBBR). J. Hazard. Mater. 187, 140-149. doi: 10.1016/j.jhazmat.2010.12.115

Feng, Y. Z., Grogan, P., Caporaso, J. G., Zhang, H. Y., Lin, X. G., Knight, R., et al. (2014). pH is a good predictor of the distribution of anoxygenic purple phototrophic bacteria in Arctic soils. Soil Biol. Biochem. 74, 193-200. doi: 10.1016/j.soilbio.2014.03.014

Feng, Y. Z., Lin, X. G., Zhang, J., Mao, T. T., and Zhu, J. G. (2011). Soil purple phototrophic bacterial diversity under double cropping (rice-wheat) with freeair CO2 enrichment (FACE). Eur. J. Soil Sci. 62, 533-540. doi: 10.1111/j.13652389.2011.01357.x

Gadhe, A., Sonawane, S. S., and Varma, M. N. (2015). Enhancement effect of hematite and nickel nanoparticles on biohydrogen production from dairy wastewater. Int. J. Hydrogen Energ. 40, 4502-4511. doi: 10.1016/j.ijhydene.2015. 02.046

He, S. Y., Feng, Y. Z., Ni, J., Sun, Y. F., Xue, L. H., Feng, Y. F., et al. (2016). Different responses of soil microbial metabolic activity to silver and iron oxide nanoparticles. Chemosphere 147, 195-202. doi: 10.1016/j.chemosphere.2015. 12.055

Huang, F., Ge, L., Zhang, B., Wang, Y., Tian, H., Zhao, L. P., et al. (2014). A fullerene colloidal suspension stimulates the growth and denitrification ability of wastewater treatment sludge-derived bacteria. Chemosphere 108, 411-417. doi: 10.1016/j.chemosphere.2014.02.042

Idi, A., Nor, M. H. M., Wahab, M. F. A., and Ibrahim, Z. (2015). Photosynthetic bacteria: an eco-friendly and cheap tool for bioremediation. Rev. Environ. Sci. Biotechnol. 14, 271-285. doi: 10.1007/s11157-014-9355-1

Iram, M., Guo, C., Guan, Y. P., Ishfaq, A., and Liu, H. Z. (2010). Adsorption and magnetic removal of neutral red dye from aqueous solution using Fe3O4 hollow nanospheres. J. Hazard. Mater. 181, 1039-1050. doi: 10.1016/j.jhazmat.2010. 05.119

Jiang, S., Park, S., Yoon, Y., Lee, J. H., Wu, W. M., Phuoc Dan, N., et al. (2013). Methanogenesis facilitated by geobiochemical iron cycle in a novel syntrophic methanogenic microbial community. Environ. Sci. Technol. 47, 10078-10084. doi: $10.1021 /$ es $402412 \mathrm{c}$

Kato, S., Hashimoto, K., and Watanabe, K. (2012). Methanogenesis facilitated by electric syntrophy via (semi)conductive iron-oxide minerals. Environ. Microbiol. 14, 1646-1654. doi: 10.1111/j.1462-2920.2011.02611.x

Khusnutdinova, A. N., Ovchenkova, E. P., Khristova, A. P., Laurinavichene, T. V., Shastik, E. S., Liu, J., et al. (2012). New tolerant strains of purple nonsulfur bacteria for hydrogen production in a two-stage integrated system. Int. J. Hydrogen Energ. 37, 8820-8827. doi: 10.1016/j.ijhydene.2012. 02.003

Kirkpatrick, B., Kohler, K., Byrne, M., Fleming, L. E., Scheller, K., Reich, A., et al. (2014). Human responses to Florida red tides: policy awareness and adherence to local fertilizer ordinances. Sci. Total Environ. 493, 898-909. doi: 10.1016/j. scitotenv.2014.06.083

Lalley, J., Han, C., Li, X., Dionysiou, D. D., and Nadagouda, M. N. (2016). Phosphate adsorption using modified iron oxide-based sorbents in lake water: kinetics, equilibrium, and column tests. Chem. Eng. J. 284, 1386-1396. doi: 10.1016/j.cej.2015.08.114

Lenz, M., Enright, A. M., O'aherty, V., van Aelst, A. C., and Lens, P. N. L. (2009). Bioaugmentation of UASB reactors with immobilized Sulfurospirillum barnesii for simultaneous selenate and nitrate removal. Appl. Microbiol. Biotechnol. 83, 377-388. doi: 10.1007/s00253-009-1915-x

Li, G., Liang, Z., An, T., Zhang, Z., and Chen, X. (2015). Efficient biodeodorization of thioanisole by a novel bacterium Brevibacillus borstelensis GIGAN1 immobilized onto different parking materials in twin biotrickling filter. Bioresour. Technol. 182, 82-88. doi: 10.1016/j.biortech.2015.01.120

Li, H. M., Tang, H. J., Shi, X. Y., Zhang, C. S., and Wang, X. L. (2014). Increased nutrient loads from the Changjiang (Yangtze) River have led to increased Harmful Algal Blooms. Harmful Algae 39, 92-101. doi: 10.1016/j.hal.2014. 07.002

Li, R., Morrison, L., Collins, G., Li, A., and Zhan, X. (2016). Simultaneous nitrate and phosphate removal from wastewater lacking organic matter through microbial oxidation of pyrrhotite coupled to nitrate reduction. Water Res. 96, 32-41. doi: 10.1016/j.watres.2016.03.034

Liu, B. F., Jin, Y. R., Cui, Q. F., Xie, G. J., Wu, Y. N., and Ren, N. Q. (2015). Photofermentation hydrogen production by Rhodopseudomonas sp nov strain A7 isolated from the sludge in a bioreactor. Int. J. Hydrogen Energ. 40, 8661-8668. doi: 10.1016/j.ijhydene.2015.05.001

Liu, J. F., Zhao, Z. S., and Jiang, G. B. (2008). Coating Fe3O4 magnetic nanoparticles with humic acid for high efficient removal of heavy metals in water. Environ. Sci. Technol. 42, 6949-6954. doi: 10.1021/es800924c

Lo, S. C., Shih, S. H., Chang, J. J., Wang, C. Y., and Huang, C. C. (2012). Enhancement of photoheterotrophic biohydrogen production at elevated temperatures by the expression of a thermophilic clostridial hydrogenase. Appl. Microbiol. Biotechnol. 95, 969-977. doi: 10.1007/s00253-012-4017-0

Lu, H., Zhang, G., Dai, X., and He, C. (2010). Photosynthetic bacteria treatment of synthetic soybean wastewater: direct degradation of macromolecules. Bioresour. Technol. 101, 7672-7674. doi: 10.1016/j.biortech.2010.04.074

Molday, R. S. (1984). Magnetic Iron-Dextran Microspheres US 4452773.

Nagadomi, H., Kitamura, T., Watanabe, M., and Sasaki, K. (2000). Simultaneous removal of chemical oxygen demand (COD), phosphate, nitrate and $\mathrm{H} 2 \mathrm{~S}$ in the synthetic sewage wastewater using porous ceramic immobilized photosynthetic bacteria. Biotechnol. Lett. 22, 1369-1374. doi: 10.1023/A:1005688229783

Oh, S. Y., Seo, Y. D., Kim, B., Kim, I. Y., and Cha, D. K. (2016). Microbial reduction of nitrate in the presence of zero-valent iron and biochar. Bioresour. Technol. 200, 891-896. doi: 10.1016/j.biortech.2015.11.021

Oller, I., Malato, S., and Sanchez-Perez, J. A. (2011). Combination of advanced oxidation processes and biological treatments for wastewater decontaminationA review. Sci. Total Environ. 409, 4141-4166. doi: 10.1016/j.scitotenv.2010. 08.061

Pan, B., Qiu, H., Pan, B., Nie, G., Xiao, L., Lv, L., et al. (2010). Highly efficient removal of heavy metals by polymer-supported nanosized hydrated Fe(III) oxides: behavior and XPS study. Water Res. 44, 815-824. doi: 10.1016/j.watres. 2009.10.027

Shukla, V. Y., Tipre, D. R., and Dave, S. R. (2014). Optimization of chromium(VI) detoxification by Pseudomonas aeruginosa and its application for treatment of industrial waste and contaminated soil. Bioremediat. J. 18, 128-135. doi: 10.1080/10889868.2013.834872

Stone, V., Nowack, B., Baun, A., van den Brink, N., von der Kammer, F., Dusinska, M., et al. (2010). Nanomaterials for environmental studies: classification, reference material issues, and strategies for physico-chemical characterisation. Sci. Total Environ. 408, 1745-1754. doi: 10.1016/j.scitotenv. 2009.10.035

Vaiopoulou, E., and Aivasidis, A. (2008). A modified UCT method for biological nutrient removal: configuration and performance. Chemosphere 72, 1062-1068. doi: 10.1016/j.chemosphere.2008.04.044

Vassilev, N., Fenice, M., Federici, F., and Azcon, R. (1997). Olive mill waste water treatment by immobilized cells of Aspergillus niger and its enrichment with soluble phosphate. Process Biochem. 32, 617-620. doi: 10.1016/S0032-9592(97) 00024- 1

Vecino, X., Devesa-Rey, R., Moldes, A. B., and Cruz, J. M. (2014). Formulation of an alginate-vineyard pruning waste composite as a new eco-friendly adsorbent to remove micronutrients from agroindustrial effluents. Chemosphere 111, 24-31. doi: 10.1016/j.chemosphere.2014.03.004 
Wang, W., Ding, Y., Wang, Y. H., Song, X. S., Ambrose, R. F., Ullman, J. L., et al. (2016). Treatment of rich ammonia nitrogen wastewater with polyvinyl alcohol immobilized nitrifier biofortified constructed wetlands. Ecol. Eng. 94, 7-11. doi: 10.1016/j.ecoleng.2016.05.078

Wang, X. Z., Cheng, X., Sun, D. Z., Ren, Y. W., and Xu, G. H. (2014). Simultaneous nutrient and carbon removal from azo dye wastewater using a photorotating biological contactor reactor. J. Chem. Technol. Biotechnol. 89, 1545-1552. doi: $10.1002 /$ jctb.4235

Wu, Y., He, J., Hu, Z., Yang, L., and Zhang, N. (2011). Removal of UV254 nm matter and nutrients from a photobioreactor-wetland system. J. Hazard. Mater. 194, 1-6. doi: 10.1016/j.jhazmat.2010.10.096

Wu, Y. H., He, J. Z., and Yang, L. Z. (2010). Evaluating adsorption and biodegradation mechanisms during the removal of microcystin-RR by periphyton. Environ. Sci. Technol. 44, 7743-7743. doi: 10.1021/es903761y

Xu, L., Guo, C., Wang, F., Zheng, S., and Liu, C. Z. (2011). A simple and rapid harvesting method for microalgae by in situ magnetic separation. Bioresour. Technol. 102, 10047-10051. doi: 10.1016/j.biortech.2011.08.021

$\mathrm{Xu}$, L. J., and Wang, J. L. (2012). Magnetic Nanoscaled Fe3O4/CeO2 Composite as an efficient Fenton-Like heterogeneous catalyst for degradation of 4Chlorophenol. Environ. Sci. Technol. 46, 10145-10153. doi: 10.1021/es300303f

Xu, P. A., Zeng, G. M., Huang, D. L., Feng, C. L., Hu, S., Zhao, M. H., et al. (2012). Use of iron oxide nanomaterials in wastewater treatment: a review. Sci. Total Environ. 424, 1-10. doi: 10.1016/j.scitotenv.2012.02.023
Yao, H., Lu, J., Wu, J., Lu, Z. Y., Wilson, P. C., and Shen, Y. (2013). Adsorption of fluoroquinolone antibiotics by wastewater sludge biochar: role of the sludge source. Water Air Soil Pollut. 224, 1-9. doi: 10.1007/s11270-0121370-7

Zhang, M., Gao, B., Yao, Y., Xue, Y., and Inyang, M. (2012). Synthesis of porous $\mathrm{MgO}$-biochar nanocomposites for removal of phosphate and nitrate from aqueous solutions. Chem. Eng. J. 210, 26-32. doi: 10.1016/j.cej.2012. 08.052

Zhu, G., Wang, Q., Yin, J., Li, Z., Zhang, P., Ren, B., et al. (2016). Toward a better understanding of coagulation for dissolved organic nitrogen using polymeric zinc-iron-phosphate coagulant. Water Res. 100, 201-210. doi: 10.1016/j.watres. 2016.05.035

Conflict of Interest Statement: The authors declare that the research was conducted in the absence of any commercial or financial relationships that could be construed as a potential conflict of interest.

Copyright (c) 2017 He, Zhong, Duan, Feng, Yang and Yang. This is an open-access article distributed under the terms of the Creative Commons Attribution License (CC BY). The use, distribution or reproduction in other forums is permitted, provided the original author(s) or licensor are credited and that the original publication in this journal is cited, in accordance with accepted academic practice. No use, distribution or reproduction is permitted which does not comply with these terms. 